К.О.Борисова-Желєзнова, аспірант КНУ імені Тараса Шевченка

\title{
КУЛЬТУРА І ОСОБИСТІСТЬ В ПСИХОАНАЛІТИЧНОМУ ДИСКУРСІ ТЕОРІЇ ЖАКА ЛАКАНА
}

Жодна інша риса культури, однак, не характеризує іiі краще, ніж повага та піклування про вищі форми психічної діяльності, про інтелектуальні, наукові та художні досягнення, про провідну роль ідей у житті людини.

(3.Фрейд «Невдоволеність культурою»[8])

Важко знайти таку суперечливу i, водночас, цікаву й плідну царину науки, як психоаналіз, особливо, коли це стосується трьох основних моментів життя людини: хто вона, де вона і який зв'язок простежується між цими двома константами. Концептуалізувати ці моменти можна дуже простими і знайомими термінами - «культура» i «особистість», на осмислення яких поклали роки свого життя цілі плеяди мислителів минулих століть. Утім, і від XX сторіччя нам дістався у спадок «багаж» психоаналітичного дискурсу, який не може не заворожити своєю різнобарвністю. I хоча творчий доробок таких представників цього напряму, як Фрейд, Юнг, Хорні та Фромм, досліджено на вітчизняному терені досить непогано, однак все ще бракує розвідок у хащах думки такого мислителя, як Жак Лакан. Завдяки проведеному автором аналізу західної та вітчизняної літератури можна констатувати, що з усього доробку Лакана, одного 3 найбільш складних мислителів XX сторіччя, найменш вивченим $\epsilon$ онтологічне й епістемологічне підгрунтя його концепції суб'єктивності та підхід до аналізу культури та іiі форм (мистецтво, наука, релігія) як до фундаментальних умов процесу суб'єктивації. Саме тому спробуємо коротко розглянути те, як французький мислитель комбінує, експлікує та зводить в єдине смислове поле поняття «культура» і «особистість» у своїй теорії.

Загальновідомий факт, що процеси в усіх сферах людської реальності відбуваються згідно з іншою логікою, ніж система свідомості, тобто своїм раціонально аргументованим дискурсивним полем 
вони не вичерпуються. Це засвідчує необхідність та актуальність звернення філософа до проблематики несвідомого, а культуролога до реконструювання питання про несвідоме в термінах культури. 3.Фрейд якось зазначив, що «голос інтелекту тихий, але він не стомлюється повторювати - і слухачі знаходяться» [7, 244]. Зауважимо, що голос має не лише інтелект, а й несвідоме, але він $є$ специфічним, бо найбільш промовистим стає під час свого мовчання. Якщо переходити на лаканівську термінологію, фоноцентризм тиранії інтелекту тут не діє - більшу роль відіграють зв'язки, проблеми, які $є$ не менш важливими, ніж слова. Як пише сам Жак Лакан, «відсутність мови виявляє себе в стереотипах дискурсу, де суб'єкт не стільки говорить, скільки позначає» [4, 50]. Чи має взагалі за таких умов несвідоме щось спільне з вищезгадуваним фрейдівським інтелектом, а також і з «особистістю» як такою? Автор доповіді на Римському конгресі відповідає ствердно: «Несвідоме має стосунок і до функцій уявлення, і навіть мислення» [4, 29]. Цим спільним виступає мова, точніше - несвідоме є структурованим як мова, тобто його характерною рисою є міцний зв'язок усіх його складових чи елементів. Більше того, особистість постає як дещо більше за декартівське cogito - вона поєднує в собі як інтелект, так і несвідоме, а їх зв'язок дає дещо більше в їх сумарному поєднанні.

Саме в цій зв'язній структурованості і визначаються як найголовніша схожість, так і відмінність свідомого та несвідомого: і там і там запорукою структури є мова, але якщо в свідомому основну роль відіграють саме слова (а точніше - смисли слів), то в несвідомому окремі елементи структури відділені один від одного «проблемами», проміжками, які відіграють не менш важливу роль, ніж «повнозначні»/«прозорі» слова. Крім того, саме несвідоме в цілому також постає такими «проблемами» / «пробілами», тією частиною конкретного трансіндивідуального дискурсу, якої не вистачає суб'єкту для встановлення неперервності свого свідомого дискурсу. Щодо цього стають зрозумілими слова Лакана про те, що «несвідоме - це та глава моєї історії, яка містить білу пляму чи брехню: це глава, яка зазнала цензури» $[4,29]$. Але все це не заважає виявити істину, найчастіше вона записана в іншому місці, - просто між рядків. Наприклад, iї можна знайти на «зламах» - на тій тонкій межі, яка пролягає між несвідомими «проблемами» та свідомими словами у слідах викривлень, адже деформування форми/грані позначається на змісті, який можна відновити власним тлумаченням, узгоджуючи 
«білі плями» фальсифікованої глави зі смислом сусідніх глав історії людини. Саме історичний симптом виявляе структуру мови та розшифровується як напис, як епіграф, який врешті-решт усі забувають.

Лакан доходить висновку, що сучасна людина має досить специфічне уявлення про свою особистість: $з$ одного боку, дещо наївне, 3 іншого - досить ретельно опрацьоване. Тобто впевненість людини в тому, що вона влаштована саме певним чином, є сформованою в середовищі розпливчастих, загальноприйнятих в їі культурі понять [див. докладніше: 6, 9-10]. I тут постає інше питання: як формується та культура, яка, власне, конструює людську особистість? Відсилання до суспільного досвіду як субстанції культурного дискурсу нічого не прояснює. Адже найбільш суттєвий вимір цього досвіду якраз і задається традицією, що виникає в культурному дискурсі. Лакан вважає, що «ця традиція створює базу елементарних структур культури задовго до того, як в них вписується драма історії» $[1,145]$, про яку ми говорили вище. Тут французький мислитель підходить до важливого висновку: для опису специфіки формування людської особистості замало етнографічної дихотомії «природа-культура», - має фігурувати саме трихотомія «природа спільнота - культура», причому саме поняття «культура» Лакан зводить до мови - того, що принципово відрізняє людську спільноту від інших природних спільнот.

Структуру цієї трихотомії легше зрозуміти, якщо звернутись до онтологічного виміру концепції суб'єктивності Лакана, про яку ми згадували на самому початку. Досліджуючи «універсальне» ін.терсуб'єктивне психічне відношення, мислитель доходить висновку, що людське буття завжди є відчуженим, відпочатково воно невіддільно від буття Іншого: реальність людського - в бутті Іншого. Важко не зазначити, що проблематика Іншого є невід'ємною рисою постмодерного дискурсу. Та Лакан не просто застосував ключове поняття для філософії другої половини XX сторіччя, він надав цій темі суто психологічного відтінку, апелюючи до Іншого лише як до діалектичної єдності, до того, що конституює Реальність власного Я, людської особистості як такої. «Референтом власного Я $\epsilon$ Інший. Власне Я встановлюється в співвіднесеності з Іншим. Воно $\epsilon$ його корелятом. Рівень, на якому відбувається переживання іншого, точно визначає рівень, на якому, буквально, для суб'єкта існує власне Я» $[2,69]$. В контексті досліджуваної нами проблематики цей момент важко переоцінити з огляду на концепцію Лакана. Адже 
на його думку саме зв'язок Его з Іншим, відношення суб'єкта до «іншого себе», до подібного (саме через відношення до цього іншого його було сформовано) $є$ найважливішою структурою особистості людини. Власне «культура-мова» $є$ тим посередником, який конституює співвіднесеність особистості й Іншого - вона взагалі дає можливість для реалізації Іншого в цьому опосередкуванні, а отже, виступає тим єдиним, що може їх об'єднати.

Отже, в плані синхронії культура та її форми постають як процесуальні умови конституювання структур суб'єктивності. Їх визначення може бути сформульоване як нескінченний процес формалізації (не забуваймо про ототожнення концептів «культура» «мова»), відновлення відношень з Реальним за посередництва процедур смислоутворення. Але наслідки цих процедур відразу випадають 3-під влади людини: вони проходять процес історизації фактів, які вже відіграли достатню роль у житті особистості. Тобто вирізняються ті факти життя, які вже є підсвідомо визнаними, зазнали цензури; саме 3 них складається певне структуроване ціле. Викладення цих фактів в історичній цілісності неможливе без «пробілів» несвідомого, які постають у Лакана прикладом пунктуації, відтінюють ефекти мови та є важливим засобом регуляції переносу свідоме переходить на другий план. Як влучно зазначає мислитель, «перед нами дивовижний парадокс! Людина тут не розпоряджається. Існує дещо таке, у що вона включається і що визначає все своїми комбінаціями завчасно. Перехід людини від природного порядку до порядку культурного підпорядковується тим самим математичним комбінаціям, що слугують нам для класифікації та пояснення. (...) До операцій над числами, у відмінний від уявних образів одвічний символізм людина залучена всім своїм єством. С в людині щось таке, що саме в цьому регістрі має здобути визнання. Але те, що має дістати визнання, воно, як вчить нас Фрейд, $є$ «не вираженим, а витісненим» $[6,436]$. Відштовхуючись від цього моменту, досить легко порівняти концепти Декарта та Лакана щодо співвідношення особистості та культури, оскільки Лакан абсолютно перетворює класичне поняття «суб'єкт». Якщо в межах картезіанської традиції «суб'єкт» розглядали як певну субстанційну цілісність, як суверенний носій свідомості і самосвідомості і як ціннісну точку відліку в культурі, то, за Лаканом, навпаки, суб'єкт постає як функція культури, як точка перетину різних символічних структур та точка прикладання сил несвідомого. 
Отже, не культура є атрибутом особистості, а особистість «атрибутом» культури, яка говорить «за допомогою» суб'єкта; а сам по собі суб'єкт є «ніщо», якась «порожнеча», що заповнюється змістом символічних матриць. Звідси - постійна взаємодія між суб' єктом як носієм культурних норм і особистістю-«Я» як носієм «бажання», тобто між Символічним і Уявним - двома з трьох складових структури людської психіки (за Лаканом). Символічне намагається повністю підпорядкувати собі індивіда, тоді як завдання «Я» полягає в тому, щоб, використовуючи топоси культури, створити 3 їх допомогою власний нарцисичний образ, тобто, поставивши «Я» на місце «суб'єкта», створити собі культурне алібі. Проте французький бунтівник все ж таки спирається на плечі своїх попередників, а саме: трактування Е.Касірером особистості як сфери дії механізмів культури, як сукупності й взаємозалежності символічних форм, за усієї своєї термінологічної близькості до картезіанського концепту, все ж виявляється ближчим до проблематизації цього теоретичного плану Ж. Лаканом, ніж вітально-біологічна інтерпретація свідомого і несвідомого у руслі фрейдівської аналітики. Концепцію Лакана в цьому сенсі можна розглядати як структуралістське переосмислення фрейдівської концепції, що трактує несвідоме як культурний механізм. Зрештою у Лакана уточнюється поняття несвідомого: несвідоме, на його думку, це «мова Іншого» (порівняйте: культура розглядається ним як «місце «Ін-шого», а сам концепт «культури» - як відповідний у смисловому навантаженні концепту «мова»), але така мова, яка постійно реда-гується Уявним. Водночас: «Несвідоме - це сукупність впливів мовою на суб'єкта на тому рівні, де суб'єкт формується ефектами означуваного» $[3,136]$.

Сприймаючи лаканівську теорію як сукупність чітких, хоч i парадоксальних питань, та абсолютно логічних, хоч і епатажних відповідей, ми переходимо до наступного пункту нашої одісеї психоаналітичного дискурсу. А саме: якщо всі прояви людського духу (релігія, міф, мистецтво - тобто культура в найбільш загальному сенсі цього слова, уся множинність їі форм) є відображенням існуючої первинної структури, яка найбільш повно втілена у несвідомому чи, за Лаканом, у мові, то виникає питання: що робить мову детермінуючою структурою? Французький мислитель застосовує найбільш поширений у філософії середини XX століття хід: якщо ми хочемо щось знайти, якісь витоки наших сьогоднішніх проблем, потрібно 
апелювати до Античності. Так, Лакан звертається до сенсу, який

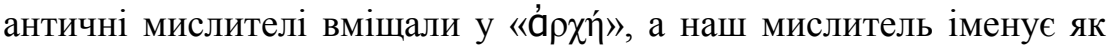
конститутивну відсутність, небуття, як джерело всіх можливих опозицій. Тут мова йде як про бінарність структури, так і про іiі смисловий конструкт, прописаний ще Ф. де Сосюром (ідеться про парадигму і синтагму в контексті класичної структуралістської структури): ланцюг означуваних формується за допомогою наявності і відсутності ознаки. Ця впорядкованість вибудовується навколо фундаментальної опозиції «так» - «ні». Опозиційна відсутність стає значимою лише в присутності чогось, що ії виявляє. Пустий простір між двома сутностями, яких немає, набуває значення лише в тому випадку, якщо усі сенси - «так», «ні» та пустий простір між ними - взаємозумовлюють одне одного. У підсумку, культура постає як «негація несвідомого» [див. докладніше: 5, 154-172]. Вище ми вже згадували Символічне та Уявне - дві з трьох складових структури людської психіки за Лаканом, а третьою такою складовою постає Реальне, яке можна назвати осердям його теорії, яке найбільше прояснює поняття культури та іiі форм. Реальне - це світ об'єктів, це світ речей та їх досвідчення особистістю, тобто все те, що лежить по інший бік мови. Власне річ як така є засвідченням відсутності в досвіді Реального, наявність у Реальному пустоти, тієї самої негації nihil, навколо якої формується означуюче. Отже, абстрактна «річ» в усіх своїх формах вираження постає як певна конкретизація культури. За логікою психаналізу вона належить до регістру сублімації, постаючи саме як конституювання пустоти. «Будь-яке мистецтво характеризується тим чи іншим способом організації навколо цієї пустоти. Релігія в усіх іiі формах являє собою той чи інший спосіб уникнути цієї пустоти, або ж цю пустоту поважати» $[5,169]$.

Як бачимо, філософська теорія Ж. Лакана постає через призму концепту суб' єктивності, онтологічним завданням якої є виявлення структури організації «особистості» як феномену та підвалин іiі формування в осерді культури та іiі форм. Актуальність та релевантність теорії Лакана визначені через такі аспекти: під час оперування термінами та ідеями французького мислителя сучасному культурологу відкривається можливість 3 досить цікавих психоаналітичних позицій співвіднести позицію особистості та символічний порядок мови, культури, соціальних та етичних норм у межах певної узагальненої теорії суб'єктивності. Крім того, лаканівські побудови відкривають широкі перспективи для дослідження ролі структур 
культури в організації діяльності несвідомого, а також поведінки та уявлень суб'єктів-особистостей.

Будучи послідовником критики Фрейдом самонаявності, тобто критики самосвідомості та самототожності суб'єкта, Лакан перебуває в руслі підозри до онтології присутності, проголошуючи, що суб'єктивність можлива лише тоді, коли суттю людської реальності $\epsilon$ онтологічна недостатність, наявність відсутності буття. 3 огляду на це, знання можливе або як інтеграція та відтворення цієї «негації» в культурну, символічну реальність, або як невротичне уникання іiі, замовчування, фантазматичне перегравання іiї в бутті думки та культури.

Варто також зазначити, що аналіз культури та їі форм у працях Лакана має на меті не просто здобуття якогось спеціалізованого культурологічного чи психологічного знання, а скоріше, виявлення та обгрунтування логіки відношень «Я-особистість» - «Інший», які, власне, й визначають специфічність побутування «суто людського» на зламі «природа - культура». Більшість форм цих відношень витісняється в процесі онтогенезу у сферу несвідомого, створюючи несвідоме особистості як певного роду смислове поле. Тож визначити закономірності відношень «Я-особистість» - «Інший» та правила, за якими вони витісняються у несвідоме, не звернувшись до аналізу культури та іiі форм, було б для Лакана неможливим. Адже аналіз культури у французького мислителя грунтується на аналізі мови суб'єкта, тобто як принципова редукція до дискурсивності, яка може обійтись без слів, але завжди лишається ними зумовленою. Але, повертаючись до проблеми «Іншого», варто також зазначити, що Лакан охарактеризував головний механізм виникнення та відтворення культури з усіма їі формами як уявну ідентифікацію з образом «ншшого». Більше того, в теорії мислителя дуже важливу роль відіграє процес формалізації Реального (третьої складової структури людської психіки) як істини та смислу, що й постає як загальний і позитивний зміст культури.

У підсумку виходить, що лаканівськая концепція поглиблює та розширює уявлення про компенсаторне та сублімаційне а́рұи́ будь-якої культури, зворотом якої є несвідоме як гарант сенсу та значення. На рівні несвідомого істина та смисл встановлюються як найбільш умовні та формальні, стійкість та значимість яких для конкретної особистості і конкретної культури підтримується комбінаторикою означуючих. 


\section{ЛІТЕРАТУРА}

1. Лакан Ж. Инстанция буквы в бессознательном, или судьба разума после Фрейда. - М., 1997. - 300 с.

2. Лакан Ж. Семинары. Книга 1. Работы Фрейда по технике психоанализа. M., 1998. - 432 c.

3. Лакан Ж. Четыре основные понятия психоанализа (Семинары: Книга XI(1964)). Пер. с фр. - М., 2004. - 304 с.

4. Лакан Ж. Функция и поле речи и языка в психоанализе. - М., 1995. - 100 с.

5. Лакан Ж. Этика психоанализа (Семинары: Книга VII (1959-60)). - М., 2006. $-416 \mathrm{c}$.

6. Лакан Ж. 'Я' в теории Фрейда и в технике психоанализа (1954/55). М., 1999. - $520 \mathrm{c}$.

7. Фрейд 3. Будущее одной иллюзии. - М., 2008. - 256 с.

8. Фрейд 3. Недовольство культурой. - Харьков, 2013. - 224 с.

Борисова-Желєзнова К.О. Культура і особистість в психоаналітичному дискурсі теорії Жака Лакана.

У статті досліджується психоаналітична теорія Жака Лакана, зокрема проблематика співвідношення в єдиному смисловому полі його концепції понять «культура» і «особистість». Розкривається зв'язок між складовими структури людської психіки та позитивним змістом культури, а також акцентується увага на проблемі несвідомого та концепті підозри до онтології присутності. Пропонується авторський погляд на взаємозв'язок цих питань в теорії французького мислителя.

Ключові слова: психоаналіз, особистість, культура, мова, несвідоме, структура.

Борисова-Железнова Е.А. Культура и личность в психоаналитическом дискурсе теории Жака Лакана.

В статье исследуется психоаналитическая теория Жака Лакана, в частности проблематика соотношения в едином смысловом поле его концепции понятий «культура» и «личность». Раскрывается связь между составляющими структуры человеческой психики и позитивным содержанием культуры, а также акцентируется внимание на проблеме бессознательного и концепте подозрения к онтологии присутствия. Предлагается авторский взгляд на взаимосвязь этих вопросов в теории французского мыслителя.

Ключевые слова: психоанализ, личность, культура, язык, бессознательное, структура.

90 ISSN2078-8142 Мультиверсум. Філософський альманах.-2016.-Випуск 1-2(149-150) 
Borisova-Zeleznova K. Culture and personality in psychoanalytic discourse theory of Jacques Lacan.

This work is devoted to the psychoanalytic theory of Jacques Lacan, in particular to the problems of correlation in a single semantic field of his concept of the terms «culture» and «identity». The article reveals the connection between components of the structure of human psyche and positive content of culture, and focuses on the problem of unconscious and concept of suspicion to the ontology of presence. Author proposes view on correlation of these issues in the theory of the French philosopher.

Key words: psychoanalysis, personality, culture, language, unconscious, structure. 